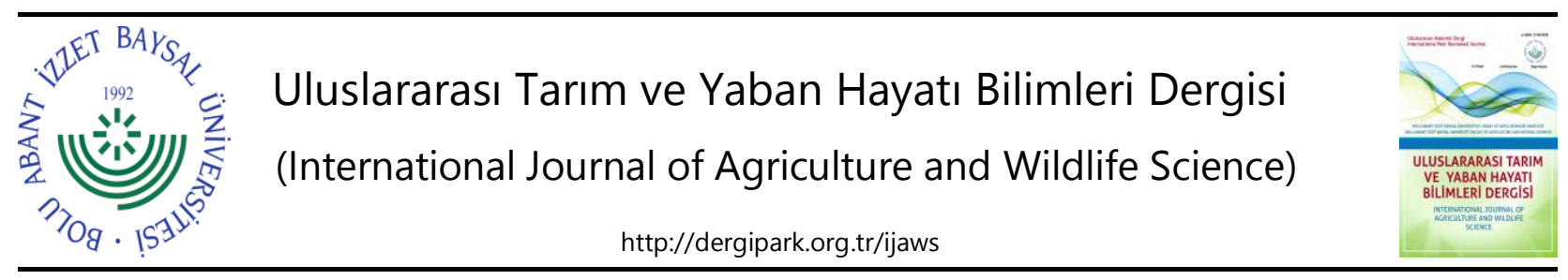

Araştırma Makalesi

\title{
Bolu ve İzmir Orman Bölge Müdürlüğü Kestane Ormanlarında Kestane Kanseri Etmeni Cryphonectria parasitica'nın Uyum Tiplerinin Tespiti ve Hipovirülenslik Değerlendirilmesi
}

\author{
Deniz Çakar ${ }^{* *}$ iD \\ Seçil Akılı Şimşek² (D) Tuncay $\mathrm{Can}^{3}$ iD, \\ Salih Maden 4 \\ ${ }^{1}$ Batı Karadeniz Ormancılık Araştırma Enstitüsü Müdürlüğü, Bolu \\ ${ }^{2}$ Çankırı Karatekin Üniversitesi Üniversitesi, Fen Edebiyat Fakültesi, Biyoloji Bölümü, Çankırı \\ ${ }^{3}$ Adana Orman Bölge Müdürlüğü, Adana \\ ${ }^{4}$ Ankara Üniversitesi, Ziraat Fakültesi, Bitki Koruma Bölümü, Ankara
}

Geliş tarihi (Received): 30.10 .2020

Kabul tarihi (Accepted): 04.01.2021

\begin{abstract}
Anahtar kelimeler:
Kestane kanseri, hipovirülent

izolatlar, vejetatif uyum
\end{abstract}

*Sorumlu yazar

denizzcakarr86@gmail.com
Özet. Bu çalışmada İzmir ve Bolu yöresinden elde edilen izolatların vejetatif uyum tipleri ilgili standart yöntemler kullanılarak belirlenmiştir. İzmir yöresinden 2015 yılında 34, 2016 yılında 7 farklı köyde seçilen aktif kanserlerden örnekler toplanmış ve elde edilen 409 izolatın 255 tanesi Avrupa uyum tiplerinden EU-12, 154 tanesi EU-1 uyum tipi olarak tespit edilmiştir. Vejetatif uyum tiplerinin bölgedeki dağılımı ortaya konmuş ve bölgeden elde edilen izolatlar içerisinde hipovirülent izolata rastlanmamıştır. Bolu yöresinde Akçakoca, Düzce, Yığılca ve Gölyaka Orman İşletme Müdürlüklerine bağlı kestane sahalarından iyileşen kanserden elde edilen 76 adet izolattan 2 adedi Avrupa uyum tiplerinden EU-12, 72 adedi ise EU-1 olarak belirlenirken 2 adedinin uyum tipi saptanamamıştır. 76 İzolatın 38 adeti hipovirülent, 38 adetinin de virülent olduğu tespit edilmiştir. Ayrıca yörede hipovirülensliğin yaygın olması ve ağaçlarda kanserden dolayı iyileşmeler olmasına rağmen kestane ormanlarında kurumalar da gözlenmiştir. Bolu yöresinde hipovirülent Cryphonectria parasitica fenotiplerinin varlığı ve yayılmaların doğal koşullarda meydana gelmesi, kestane kanseri etmeninin biyolojik kontrolü için umut vericidir. Bununla birlikte İzmir yöresi için bölgede yaygın olduğu uyum tiplerinin tespiti biyolojik mücadele çalışmalarının stratejisi için önemlidir.

\section{Determination of VC Types of Chestnut Canker Agent Cryphonectria parasitica and Evulation of Hyphovirulence in Chestnut Forest Areas in Bolu and Izmir Regional Directorates of Forestry}

\section{Keywords:}

Chestnut blight, hypovirulent isolates, vegetative compatibility

\begin{abstract}
In this study, vegetative compatibility (vc) types of isolates obtained from İzmir and Bolu regions were determined using relevant standard methods. Out of 409 isolates obtained from active canker samples collected from the selected locations of 34 and 7 villages in İzmir in 2015 and 2016, respectively, 255 were found as EU-12 of the European Vegetative compatibility types while 154 samples were EU-1 vc type. The distribution of the vc types was revealed and natural hypovirulence was not found in this region. Seventy-six isolates were obtained from bark samples from healing cankers from the samples in Akçakoca, Düzce, Yığılca, and Gölyaka locations of Bolu Forestry Management Directories. Two of these samples belonged to EU-12 vc type, while 72 of them were EU-1. The remaining two isolates did not match any of the two vc types. Out of 76 isolates, 38 were found hypovirulent and 38 were virulent. Hypovirulence was so widespread in this region and in spite of the widespread hypovirulence drying of chestnut trees was also observed. The presence of hypovirulent Cryphonectria parasitica phenotypes and the occurrence of spreading under natural conditions in the Bolu region are promising for the biological control of chestnut cancer disease. For the Izmir region, determining the vc types that are common in the region is important for the strategy of biological control studies.
\end{abstract}




\section{Giriş}

Son yıllarda kestane ağaçlarında yoğun olarak kurumalara yol açan bazı hastalıklar ortaya çıkmıştır. Bu hastalıklardan biri de Cryphonectria parasitica (Murrill) M.E. Barr [syn: Endothia parasitica (Murr.) (anamorf: Endothiella sp.)] adlı fungusun neden olduğu kestane kanseri olarak adlandırılan hastalıktır. Cryphonectria parasitica, Doğu Asya orjinli bir fungus olup ilkin Çin, Japonya ve Kore'de rapor edilmiştir (Myburg ve ark., 2004; Lee ve ark., 2005; Rigling ve Prospero, 2018). Hastalık etmeni Kuzey Amerika ve Avrupa'ya enfekteli bitki materyallerinin ithalatı ile bu ülkelerden taşınmıştır (Griffin, 1986). Hastalık Amerika'da ilk olarak 1904 yılında New York'ta tespit edilmiştir (Roane ve ark., 1986; Anagnostakis, 1987; Elliott ve Swank, 2008; Evans ve Finkral, 2010). Avrupa'da ise ilk kez 1938 yılında İtalya'da görülmüştür (Heiniger ve Rigling, 1994). Kestane ağacı ülkemizin önemli bir orman ağacı olup, Birleşmiş Milletler Gıda ve Tarım Örgütü (Food and Agriculture Organization of the United Nations = FAO)'nün 2019 istatiksel verilerine göre; Türkiye 72,655 bin ton üretim ile Dünya'da 4. sırada yer almaktadır (FAOstat, 2019). Orman Genel Müdürlüğü Kestane Eylem Planına (2013) göre ise 262,045 ha saf ve karışık kestane ormanımız mevcuttur. Bu alanın 10,212 ha'ı Bolu, 4,108 ha'ı ise İzmir Orman Bölge Müdürlüğü sınırları içinde bulunmaktadır (OGM, 2014a).

Kestane kanseri ülkemizde 1967 yılından bu yana tüm kestane alanlarında bulunmakta ve ciddi kurumalara neden olmaktadır (Coşkun ve ark., 1999; Gürer ve ark., 2001; Akıllı ve ark., 2009). Bu hastalığın kestanelere ciddi şekilde zarar vermesi, gittikçe yayılması ve etmene karşı mücadelede yetersiz ve başarısı olunması nedeniyle; odunu ve meyvesinden yararlanarak geçimini sağlayan birçok insan ekonomik olarak etkilenmektedir. Ayrıca oldukça yüksek fiyatla piyasası ve birçok yararı olan kestane balı üretimi de bu hastalık nedeniyle olumsuz etkilenmektedir. Bir karantina hastalığı olmasına rağmen önlemler bu hastalığın tüm Dünya'da yayılmasına engel olamamıştır (EPPO, 2005).

Hastalık etmeninin eşeyli dönem fruktifikasyon organları olan peritesleri 10-20'lik gruplar halinde bulunur. Askosporlar $10 \times 4 \mu \mathrm{m}$, şeffaf iki hücreli ve bölmede daralmıştır. Konidiler sarımtırak iplikçikler şeklinde çıkarlar, düz veya hafif büküktürler, şeffaf, 2-3 x $1 \mu$ m'dir. Etmen eşeyli ve eşeysiz üreme göstermektedir. Hem eşeyli hem de eşeysiz sporlar stroma içinde oluşmaktadır. Peritesler, stroma içinde belirgin bir şekilde oluşmaktadır Eşeysiz sporlar ise stroma içinde kadehe benzeyen geniş ağızlı bir yapı içinde oluşmaktadır (EPPO, 2005).

Hastalık, girdiği tüm bölgedeki kestanelere ciddi boyutlarda zarar vermektedir. Ancak daha sonra bazı yerlerde hastalığın virülensliğinin azaldığı ve ağaçlarda iyileşmeler olduğu gözlemlenmiş olup, bu da C. parasitica'nın hipovirülent strainin doğadaki varlığına dayandırılmaktadır. Etmen fungus dsRNA içeren Cryphonectria Hypo Virus (CHV) -1, 2, 3 ve 4 olarak adlandıılan virüsler tarafından enfekte edilmekte ve böylelikle fungusun saldırganlığında azalma olmaktadır (Heiniger ve Rigling, 1994; Perlerou ve Diamandis, 2006). Fungusun sitoplazmasında bulunan bu virüsler bulaşık olmadığı funguslara ancak uyumlu olduğu fungus hiflerinin kaynaşması yoluyla bulaşırlar (Anagnostakis, 1977; Jaynes ve Elliston, 1980; Griffin ve ark., 2004; Milgroom ve Cortesi, 2004; Perlerou ve Diamandis, 2006). Bu virüsler arasında Avrupa'da en çok yayılım alanına sahip ve en iyi bilineni CHV-1'dir (Allemann ve ark., 1999). Kuzey Amerika'da birkaç alan dışında CHV-1'e rastlanmamış olup (Peever ve ark., 1997; Griffin, 1999; Anagnostakis, 2001; Liu ve ark., 2002) bu bölgede daha çok CHV-2 ve CHV-3 yaygınlık göstermektedir. CHV-2 New Jersey (Hillman ve ark., 1992; Hillman ve ark.,1994; Chung ve ark., 1994) ve Çin 'de bir bölgede bulunmuştur (Peever ve ark., 1998). CHV-3'e doğal olarak Michigan (Fulbright ve ark., 1983) ve Ontario'da rastlanmış (Melzer ve Boland, 1999) fakat Asya'da rastlanmamıştır (Peever ve ark., 1998; Liu ve ark., 2003). CHV-4 Kuzey Amerika'nın batısı Appalachian'da geniş bir alanda yayılış göstermektedir (Peever ve ark., 1997; Liu ve ark., 2002). CHV-4 genom yapısından dolayı taksonomik olarak bir hipovirüstür fakat diğerlerine benzemekle birlikte virülensliği diğerlerine göre az ya da hiç görülmemektedir (Enebak ve ark., 1994; Peever ve ark., 2000; Milgroom ve Cortesi, 2004).

Hipovirülent C. parastica ile enfeksiyonlu kestane ağaçlarında yeni kallus dokusu geliştiği için kanserlerin etkinliğini azalmakta ve iyileşme görülmektedir. Böyle kanserler hafif şişkin görünümde olup ağaca az ya da hiç zarar vermemektedirler. Fungus miselyumunun ağacın en dış kabuk tabakası ile sınırlandırılması ile yüzeysel kanserler oluşmakta ve onlara iyileşen kanserler denilmektedir (Milgroom ve Cortesi, 2004).

Ülkemizde uyum tiplerinin belirlenmesi amacıyla birçok çalışma yapılmıştır. Çeliker ve Onoğur $(1998,2009)$ gerçekleştirdikleri bir seri çalışmada Marmara ve Ege Bölgelerinden 19 farklı lokasyondan elde ettikleri 388 C. parasitica izolatının \%93.3 oranında EU-1 ve \%6.7 oranında EU-12 olmak üzere iki uyum tipi içerisinde yer aldıklarını tespit etmişlerdir. Aynı çalışmada EU-1 tüm örnek alınan yerlerde bulunurken EU-12 sınırlı bölgelerde, Marmara Bölgesi (Balıkesir-ivrindi) ve Ege Bölgesi (İzmir-Beydağı ve Aydın)'inden elde edilmiştir. Coşkun ve ark. (1999) 10 İtalyan vc tipi ve Avrupa uyum tiplerinden EU-4 ve EU-5'i kullanarak Marmara ile Doğu ve Batı Karadeniz bölgelerinden 181 kestane sahasından, 265 izolatta uyum tiplerini testlemelerine rağmen izolatların hangi Avrupa uyum tipine karşılık geldiği anlaşılmamıştır. Gürer ve ark. (2001) Marmara ve Karadeniz Bölgesinden 134 C. 
Çakar ve ark., Bolu ve İzmir Orman Bölge Müdürlüğü Kestane Ormanlarında Kestane Kanseri Etmeni Cryphonectria parasitica'nın Uyum Tiplerinin Tespiti ve Hipovirülenslik Değerlendirilmesi

parasitica izolatı toplamış ve 63 Avrupa uyum tipi ile eşleştirmişlerdir. Araştırmacılar bu izolatların, EU-1 uyum tipine girdiklerini belirtmiştir. Döken ve ark. (2004) Aydın ilinde 97 izolatla yaptıkları çalışmada, 2 uyum tipi olarak EU-1 ve EU-12'yi tespit etmiştir. Akıllı ve ark. (2009) Karadeniz Bölgesinden, 11 ilde 32 lokasyondan elde ettiği 296 izolatın, 5 uyum tipine (EU-1, EU-12, EU-14, EU-2, EU-5) girdiğini ifade etmiştir. Ayrıca araştıııılar, beş uyum tipinin tümünün sadece Kastamonu Orman Bölge Müdürlüğü içerisinde olduğunu belirtmiştir. Uyum tiplerinden EU-1 \%90.8 ile tüm bölgede görülürken, EU-12 \%6.8, EU-14, EU-2 ve EU-5 ise \%1.5 oranında belirlenmiştir. Erincik ve ark. (2011) Aydın'da \%23 EU-12, \%77 EU-1, uyum tipi elde ederken, İzmir'de \%30 EU-1, \%70 oranında EU-12 tespit etmiştir. Akıllı ve ark. (2013) tarafından, Bursa ve Yalova illerinde yapılan çalışmada 3 yıl içinde 15 lokasyondan, 198 izolat elde edilmiş ve bu izolatların uyum tiplerinin EU-1 olduğu bildirilmiştir. İzmir bölgesinde FAO (Gıda ve Tarım Örgütü) ve Orman Genel Müdürlüğü işbirliği ile yapılan bir proje kapsamında (FAO 20122014) Avrupa uyum tiplerinden EU-1 ve EU-12'nin bu yörede yaygın olarak görüldüğü ifade edilmiştir (FAO 2014). İzmir, Manisa, Muğla ve Denizli illerinde kestane üretiminin önemli olduğu 19 köyden 268 izolat elde eden Daldal (2015), İzmir ilinde EU-1, EU-2 ve EU-12 olmak üzere 3 vc tipi, Denizli ve Manisa illerinde ise, EU-1 ve EU-12 olmak üzere 2 vc tipi tespit etmiştir. Mangıl (2017) Doğu Karadeniz'de Artvin, Rize ve Trabzon illerinden seçilen 3 farklı bölgeden 344 izolat elde etmiştir. Seçilen lokasyonlardaki kestane ağaçlarından kanserli dokular alınmış ve elde edilen izolatların, 235'i EU-1 (\%68.3), 23'ü EU-17 (\%6.7), 21'i EU-12 (\%6), 14'ü EU-3 (\%4) olarak bulunurken 51 izolatın çalışılan hiçbir uyum tipine girmediği bildirilmiştir.

Dünya literatürleri incelendiği zaman bölge bazında patojen popülasyonlarının vc tip dağılımlarında ve hipovirülenslik durumlarının bir varyasyon içerisinde olduğu görülmektedir. Türkiye'de vc tip dağılımları üzerine birçok çalışma yapılmış ve en son yapılan çalışmalardan biri de 2012-2014 yılları arasında FAO ve Orman Genel Müdürlüğü'nün işbirliği ile yürütülen bir proje kapsamında İzmir bölgesinde uyum tipleri belirlenmiş ve hipovirülent izolatlarla biyolojik mücadele çalışması başlatılmış ve başarılı sonuçlar alınmıştır. Bu çalışmada ise, İzmir yöresinde kestane ağacının yetiştiği farklı bölgelerde bulunan hastalık etmeninin uyum tiplerinin çıkarılması ve başarılı olan biyolojik mücadelenin yaygınlaştırılması hedeflenmiştir. Ayrıca İzmir bölgesinde yürütülen Çeliker ve Onoğur (1998, 2009), Erincik ve ark. (2011) ve FAO (2014) çalışmalarında belirlenen durumlardaki değişimin incelenmesi de amaçlanmıştır. Ayrıca, Bolu bölgesinde de hastalığın uyum tiplerinin çıkarılması hedeflenmiş olup, hipovirülenslik değerlendirilmesi sonucu hipovirülensliğin görülmediği veya \%50'den az iyileşmiş kanserlerin bulunduğu bölgeler için hipovirülent izolatlarla biyolojik mücadele çalışmalarının başlatılması amacıyla bu yöre hipovirülenslik açısından ilk olarak değerlendirilmiştir.

\section{MATERYAL VE METOT}

\section{Örneklerin Toplanmast}

Bolu ve İzmir yöresinde örneklerin alımı, 2015 ve 2016 yıllarında her yörenin koşullarına, saha ve kanserlerin durumuna göre kestane alanları ile orantılı olarak amaçlı örnekleme yapılmıştır. Bolu Orman Bölge Müdürlüğü sahalarında kestane kanserinin durumunu genel olarak ortaya koymak ve uyum tipi tespiti ile yeni hipovirülent izolat elde etmek için kestane alanları gezilmiş ve değerlendirmeler yapılmıştır. Bolu Orman Bölge Müdürlüğ̈’nde sahalar arazi koşullarına göre bölmeler (Kestane karışımda 1. öncelikli ve 2. öncelikli arazi duruma göre 3. öncelikli) gezilerek iyileşen kanserlerden kabuk örneği toplanmıştır. Sahaların kestane kanseri açısından durum değerlendirmesi yapılmıştır.

Her iki sahada da örnekler her aktif kanserlerin sağlam doku ile kanserin birleştiği yerden $1 \mathrm{~cm}$ çaplı bir mantar delici ile kambiyum dokusunu da içerecek şekilde kanserin iki ucu ve ortası olmak üzere 3 yerinden kabuk örneği şeklinde alınmıştır (OGM, 2014b). Örnekler havlu kâğıtlara sarılı olarak ve gerekli bilgiler etiketlenerek laboratuvara getirilmiştir.

Bolu Orman Bölge Müdürlüğü'ne bağlı 4 işletme müdürlüğü (Akçakoca, Düzce, Yığılca ve Gölyaka)'nden 107 kabuk örneği alınmıştır. Kestane sahalarında alanların özelliklerine, arazi koşullarına, kanserin durumuna ayrıca meşcere haritaları ve kestane üretimi dikkate alınarak köyler gezilmiş, kestane yoğunluğuna göre değerlendirilerek örneklemeler yapılmış olup; Akçakoca Orman İşletme Müdürlüğü'ne bağlı 4 İşletme Şefliği (Deredibi, Aktaş, Altınçay ve Cumayanı)'nde 46 bölme gezilerek sahada kestane ağaçları incelenmiş olup, alanı temsilen örnek alınıma uygun bulunan 66 örnek alınmıştır. Düzce Orman Işsletme Müdürlügü̈ne bağlı 2 İşletme Şefliği (Melen ve Konuralp) 21 bölme gezilerek sahada kestane ağaçları incelenmiş olup, alanı temsilen 22 örnek alınmıştır. Yığılca Orman İşletme Müdürlügü'ne bağlı 2 İşletme Şefliği (Karadere ve Melendere) 6 bölme gezilerek sahada kestane ağaçları incelenmiş olup, alanı temsilen 14 örnek alınmıştır. Gölyaka Orman Işsletme Müdürlüğü'ne bağlı 1 İşletme Şefliği (Kardüz) 3 bölme gezilerek sahada kestane ağaçları incelenmiş olup, alanı temsilen 5 örnek alınmıştır. 
İmir yöresinde kestane sahalarını temsil edecek şekilde araştırmada hedeflenen sayıda kestane kanseri bulunmuş ve kabuk örneği alınmıştır. Bu amaçla, bu yöreden 2015 yılında Ödemiş'e bağı 10 köyden 185 örnek, Tire'ye bağlı 7 köyden 68 örnek, Kiraz'a bağlı 11 köyden 96 örnek ve Beydağ ilçesine bağlı 6 köyden 60 örnek alınmış olup, 34 farklı köyden toplam da 409 kabuk örneği alınmıştır. 2016 yılında ise Ödemiş'e bağlı 4 köyden 31 örnek, Kiraz'a bağlı 2 köyden 13 örnek ve Demirci (Manisa)'ye bağlı 1 köyden 8 örnek alınmış olup, 7 köyden toplam da 52 örnek alınmıştır.

Bolu ve İzmir bölgelerinde farkıı olarak çalışılmasının nedeni, İzmir yöresinde kestane ormanlarında sosyal problemlerin olması, mülkiyetin ormana ait olup, kullanıcılığının vatandaşa ait olmasıdır. Kestane bahçeleri ve ormanları birbirinden ayırmak zor olmuştur. Ayrıca bu yörede hipovirülensliğin olmaması nedeniyle ormanlık alanlarda saha değerlendirilmesi yapılmamıştır. Bolu yöresinde hipovirülensliğin yaygın olması, meşcere olarak alanların değerlendirilmesinin mümkün olması nedeniyle bu yörede Orman İşletme Müdürlüklerine bağlı ormanlık alanlarda değerlendirmeler yapılmıştır.

Bolu Orman İşletme Müdürlüğü sahalarında hipovirülenslik değerlendirilmesi Kestane Hastalıklarına Karşı Standart Çalışma Yöntemleri Kitapçı̆̆ı (SÇY)'na göre yapılmıştır. İlk olarak değerlendirilme yapılacak 2-4 ha alanda taç seyrelmesi veya kurumaya yaklaşık bir oran verilmiştir. Meşcere içerisinde 2 ha alanda ağaçlar üzerinde iyileşmiş kanserlerin varlığı gözlemsel olarak tespit edilmiş ve bu alana giren ağaçlar sayılmış ve bu alanda iyileşmiş kanserlerin bulunduğu ağaç sayılarının \%50'den fazla olduğu alanlar hipovirülenslik açısından yaygın olduğu sonucuna varılmıştır. İyileşmiş kanserlerin bulunduğu ağaçların tepe tacı seyreklik oranı da \%30, \%60 ve \%60'tan fazla seyrelme durumuna göre değerlendirilmiştir. Bu oranlar gözlemsel olarak verilmiştir.

\section{Tester İzolatların Temini}

Swiss Federal Institute for Forest, Snow and Landscape Research, WSL (İsviçre Federal Orman, Kar ve Peyzaj Araştırmaları Enstitüsü)'den temin edilen Avrupa uyum tiplerinden Türkiye'de varlığı bilinen EU-1, EU-12 çalışmaya dahil edilmiştir. İzmir ve Bolu yöresinde elde edilen izolatlar için EU-1 ve EU-12 Avrupa uyum tipleri kullanılmıştır. Bolu yöresinde uyum tipleri belirlenemeyen izolatlar için Türkiye'de olası uyum tiplerinden Avrupa EU-2, EU-3, EU-5, EU-7, EU-26 ve EU-44, uyum tipleri çalışmaya dahil edilmiştir.

\section{Cryphonectria parasitica Izolasyonu}

Bolu yöresinden alınan 107 kabuk örneği ve İzmir yöresinden alınan 461 kabuk örneği önce \%1'lik sodyum hipoklorür içinde $3 \mathrm{dk}$ tutulmuş ve steril kurutma kağıdında kurutulmuştur. Bu parçalardan alınan 2-3 mm büyüklüğünde kesitler PDAmb (PDA $40 \mathrm{~g}$, methionin $100 \mathrm{mg}$, biotin $1 \mathrm{mg}$, saf su $1000 \mathrm{ml}$ ) besi ortamı içeren Petri kaplarına yerleştirilmiş ve $26^{\circ} \mathrm{C}$ sıcaklıkta, 12 saat aydınlık 12 saat karanlıkta 7 gün inkübasyona bırakılmıştır. Gelişen fungusların stereomikroskop altında gelişen hif uçlarından alınarak fungusun saf izolatları elde edilmiş ve eğik agarda $4^{\circ} \mathrm{C}^{\prime}$ de buzdolabında ve cryotüplerde $-80^{\circ} \mathrm{C}^{\prime}$ de saklanmıştır.

\section{Kültürel Özelliklerine Bakılarak Hipovirülent İzolatların Belirlenmesi}

Çalışma kapsamında izole edilen C. parasitica izolatları PDAmb ortamında kültüre alınmış ve 7 gün $25^{\circ} \mathrm{C}$ karanlıkta, 5 gün yaygın laboratuvar ışığı altında geliştirilmiştir. Gelişen C. parasitica izolatları arasından hipovirülent izolatlar öncelikle fenotipik ve morfolojik özelliklerine göre yani kültürlerdeki renk oluşumuna göre belirlenmiştir. Kültürlerde turuncu renkte gelişen izolatlar virülent, beyaz renkte gelişenler hipovirülent olarak kabul edilmişlerdir (Şekil 1) (Bissegger ve ark.,1997).

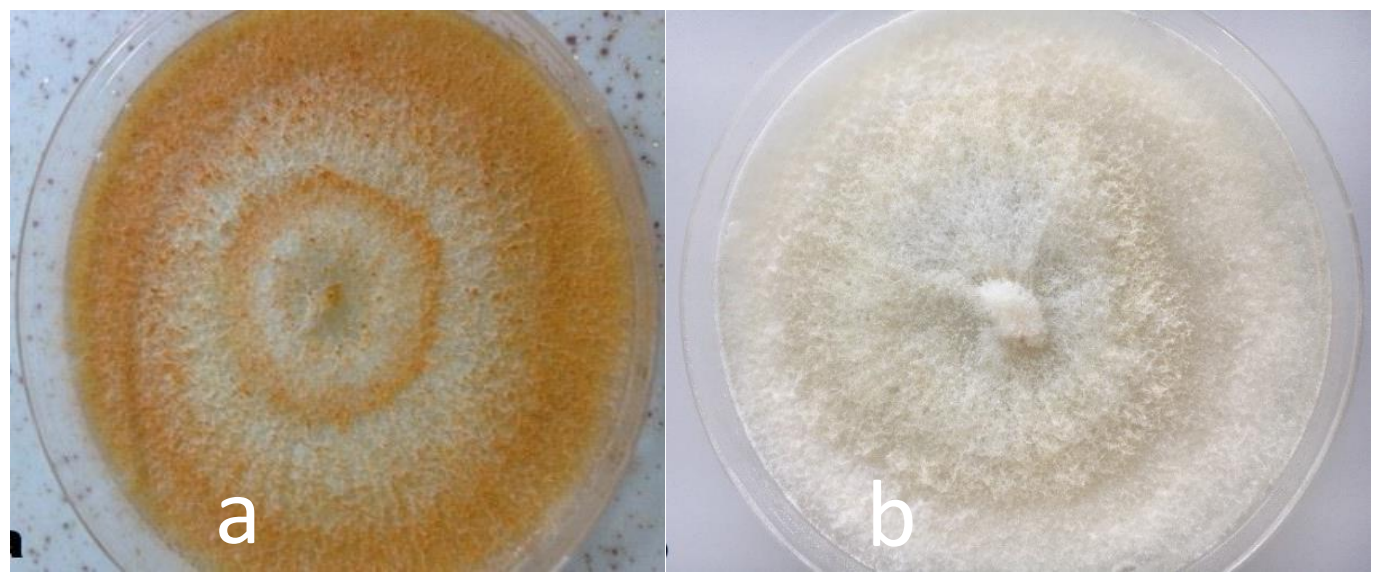

Şekil 1. Cryphonectria parasitica'nın virülent izolatın (a) hipovirülent izolatın (b) kültürdeki gelişmeleri. Figure 1. Cultural characteristics of virulent (a) and hypovirulent (b) Cryphonectria parasitica isolates. 


\section{Phenol Oxidase Enzim Aktivitesi (Bavendamm Testi) ile Hipovirulensliğin Belirlenmesi}

Bolu bölgesinden hipovirülent kanser olduğu düşüncesiyle alınan 13 izolat laboratuvar ortamında hipovirülent kültürel özellikleri net olarak göstermediği için bu izolatlar Rigling ve ark. (1989)'in yöntemi kullanılarak Bavendamm testine tabi tutulmuşlardır. Bavendamm ortamı $(5 \mathrm{~g}$ tannik asit, $15 \mathrm{~g}$ malt ekstrakt, $20 \mathrm{~g}$ agar, 1000 $\mathrm{ml}$ saf su) hazırlamak için önce malt ekstrakt agar hazırlanıp, pH'ı NaOH ile 4.5'e ayarlanmış olup, ayrı bir kapta tannik asit çözeltisi hazırlanmıştır. Bunlar ayrı ayrı otoklav edilip ve petri kaplarına dökülmeden önce karıştırılmış ve PDAmb'de geliştirilen fungus izolatlarından alınan $5 \mathrm{~mm}$ çaplı diskler bu ortama aktarılıp ve $20^{\circ} \mathrm{C}$ karanlıkta inkübasyona bırakılmıştır. Bu testte, dört günlük inkübasyondan sonra koyu renk gösteren izolatlar virülent, açık renkte olanlar ise hipovirülent olarak kabul edilmektedir (Şekil 2).

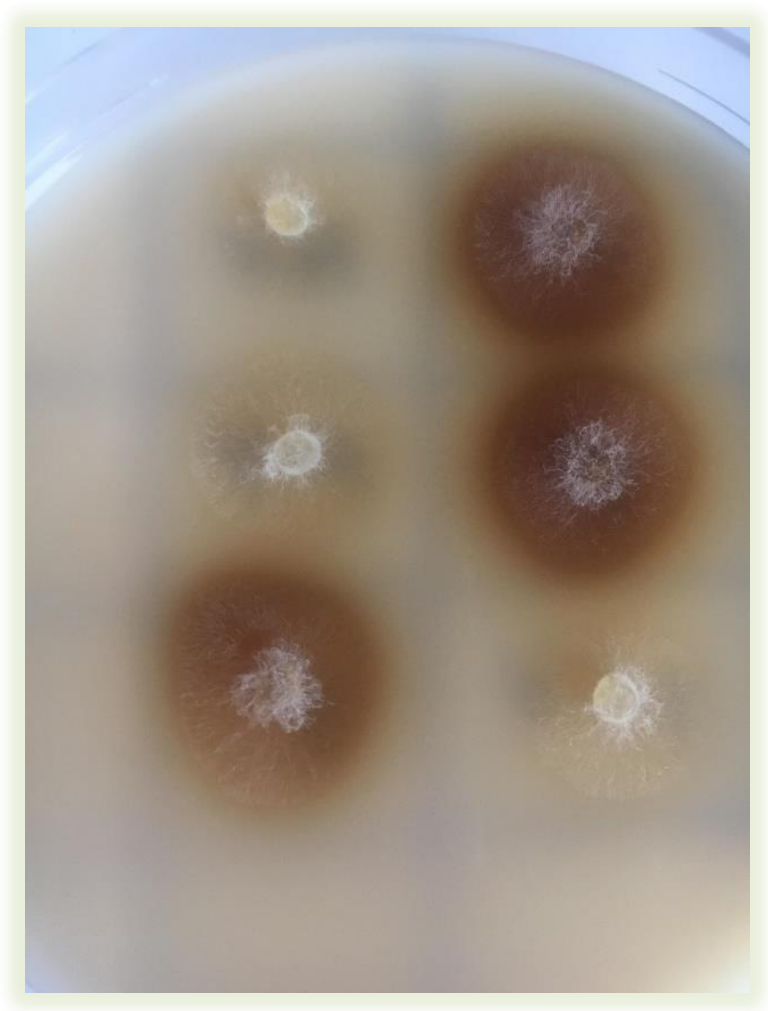

Şekil 2. Bavendamm testinde virülent (koyu renkte) ve hipovirülent (açık renkte) izolatların gelişimi. Figure 2. Growth of virulent (dark colour) and hypovirulent (light colour) isolates in Bavendamm test.

\section{Cryphonectria parasitica Izolatlarinin Vejetatif Uyum Tiplerinin (vc) Belirlenmesi}

İzolasyonlar sonucunda, iki farklı bölgeden (Bolu ve İzmir) toplanan kabuk örneğinden elde edilen C. parasitica izolatlarının vejetatif uyum tipleri belirlenmiştir. Bu amaçla, izolatların PDAmb ortamında saf olarak gelişen kültürlerinden steril iğne ile sporulasyon yapan kısımdan bir miktar alınmış, yine PDAmb ortamında $2 \mathrm{~mm}$ aralıklarla, öncelikle daha önce ülkemizde varlığı tespit edilen EU-1 ve EU-12 vc tipleri ile eşleştirilmiş ve 7 gün karanlıkta 7 gün ise yaygın gün ışığında tutulmuştur. Eşleştirilen diskler arasında kuvvetli baraj ve sporulasyon zonları oluşturanlar veya sporulasyon oluşturmayıp baraj zonları oluşturanlar uyumsuz, baraj zonları oluşturmayanlar ise uyumlu olarak değerlendirilmiştir (Şekil 3) (Anagnostakis ve ark., 1986; Bissegger ve ark., 1997). Uyum çalışmaları 2 tekrarlı yapılmıştır. 


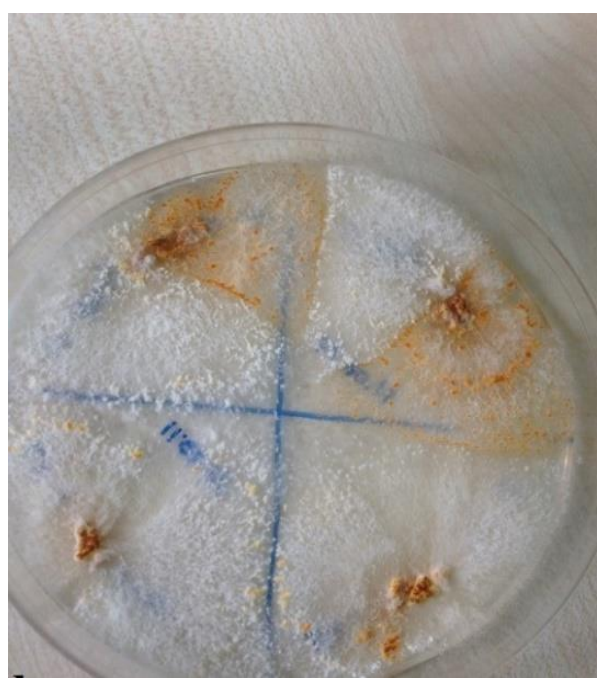

Şekil 3. Kültürde baraj zonlarından görünüm; baraj zonu oluşturan izolat (üstte), baraj zonu oluşturmayan izolat (altta). Figure 3. Appearance of barrage zones on culture. No barrages (bottom), clear barrage zones (top).

\section{BULGULAR}

Bolu Orman Bölge Müdürlüğü'nden 3 orman işletme müdürlüğü sınırlarından toplam 107 örnek incelenmiş ve bunlardan 76'sında kestane kanseri etmeni C. parasitica varlığı tespit edilmiştir. Bu kabuk örneklerinin kültürel özelliklerine göre 28 tanesi Hipovirülent (HV: doğal iyileşme), 35 tanesi ise Virülent (V: aktif kanser) C. parasitica olarak tanımlanmıştır. Kültürel özelliklerine göre net olarak tanımlanamayan 13 izolat Bavendamm testine tabi tutulmuş, bunların 3 adedi bu test sonucuna göre virülent 10 adedi ise hipovirülent olarak tanımlanmıştır. Sonuçta Bolu bölgesinde iyileşen kanserlerden elde edilen 76 izolatın 38'i virülent, 38'i ise hipovirülent izolat olarak belirlenmiştir.

İzmir Orman Bölge Müdürlüğü'nden 2015 yılında İzmir sınırlarında 34 farklı köyden toplam 409 kabuk örneğinden 359 tane C. parasitica izolatı elde edilmiştir. Yapılan izolasyonlarda İzmir yöresinde hipovirülent izolata rastlanmamıştır. 2016 yılında ise Mart ayı itibariyle 7 farklı köyden (Manisa, Demirci dahil) 52 kabuk örneği toplanmış ve 50'sinde C. parasitica tespit edilmiştir (Çizelge 1).

Çizelge 1. Bolu ve İzmir bölgelerinden alınan kanserli örnek ve elde edilen Cryphonectria parasitica izolat sayısı. Table 1. Numbers of the canker samples taken from Bolu and Izmir Regions and Cryphonectria parasitica isolates.

$\begin{array}{cccc}\begin{array}{c}\text { Örnek Alınan } \\ \text { Bölge } \\ \text { Müdürlüğü }\end{array} & \begin{array}{c}\text { Örnek } \\ \text { Sayısı }\end{array} & \text { Elde Edilen C. parasitica izolatlarının } \\ \text { virülensliği }\end{array}$

*izmir yöresinde 2015 ve 2016 yıllarında alınan toplam örnek sayısı (409+52).

\section{Kanser Örneklerinden Elde Edilen Cryphonectria parasitica İolatlarının Uyum Tipleri}

Elde edilen bu izolatlar vejetatif uyum tiplerinin belirlenmesi için yöntem kısmında belirtildiği şekilde, Avrupa uyum tipleri ile eşleştirilmiştir. Bolu'da 76 izolatta yapılan uyum çalışmalarında ise 72 tanesi EU-1, 2 tanesi EU-12 olarak tespit edilmiştir. Elde edilen 2 izolatın vejetatif uyum grubu test edilen gruplarla uyuşmamıştır. İzmir ilinden 2015 ve 2016 yılında elde edilen 409 C. parasitica izolatının vejetatif uyum çalışmaları sonuncunda 154 tanesi EU1, 255 tanesi EU-12 olarak tespit edilmiştir. Bolu ve İzmir yöresinden (İzmir Orman Bölge Müdürlüğü sınırları, Manisa dahil) elde edilen izolatların uyum tipleri dağılımı harita üzerinde gösterilmiştir (Şekil 4, Şekil 5, Şekil 6, Şekil 7). 


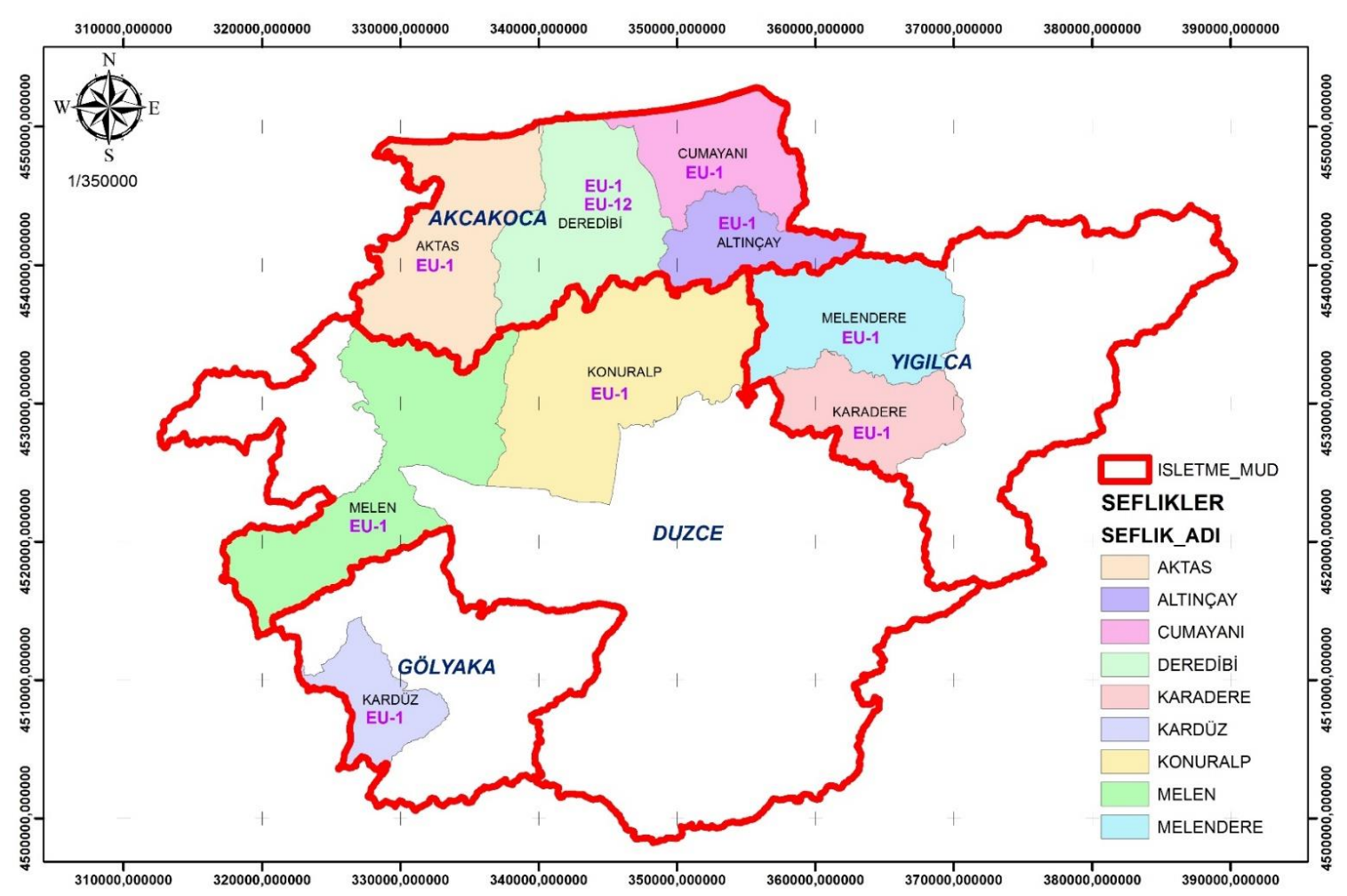

Şekil 4. Bolu Orman Bölge Müdürlüğü sınılarında kestane kanseri etmeni Cryphonectria parasitica'nın uyum tiplerinin dağıımı. Figure 4. Distribution of vc types of Cryphonectria parasitica in Bolu Regional Directorate of Forestry.

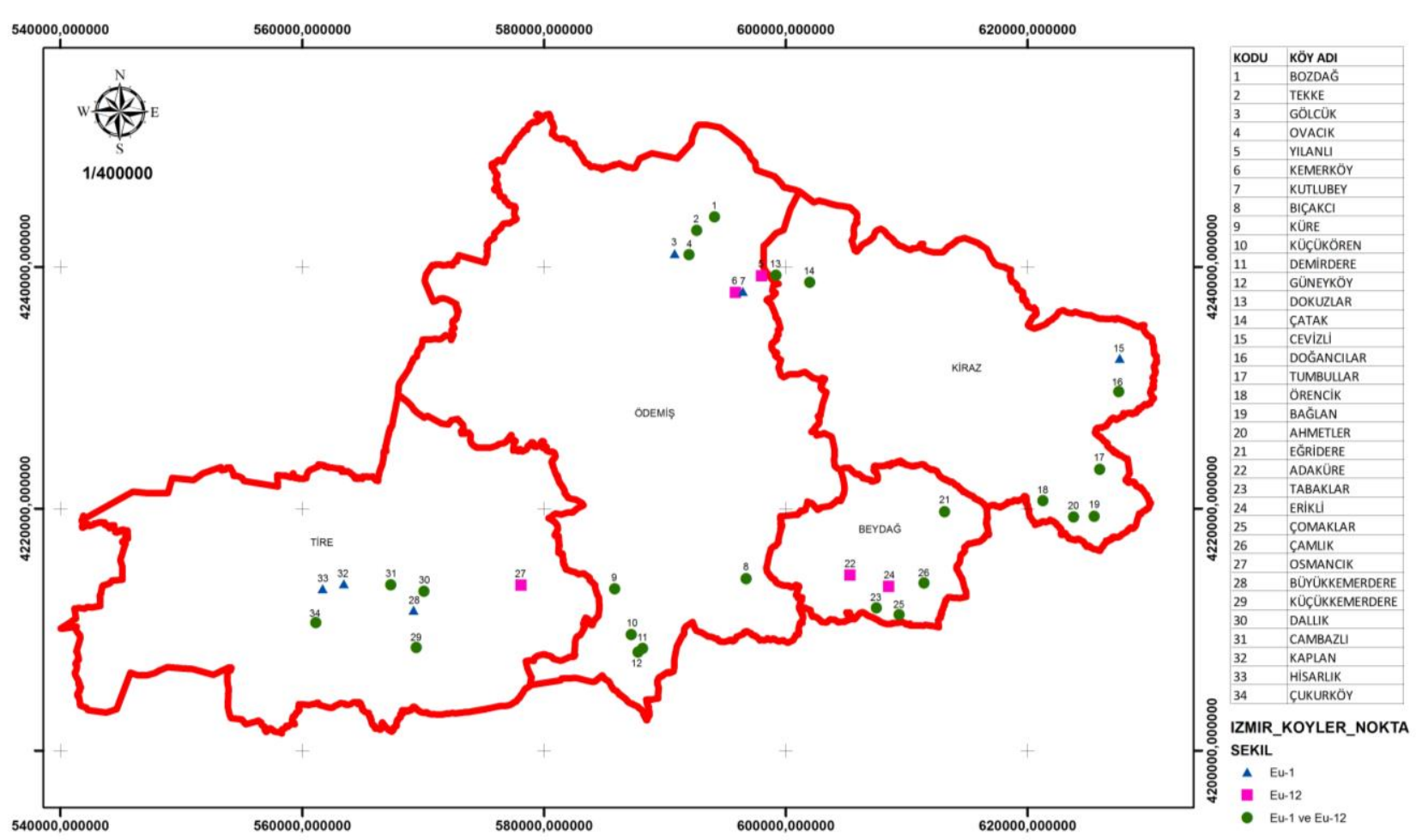

Şekil 5. İzmir yöresinde kestane kanseri etmeni Cryphonectria parasitica'nın uyum tiplerinin dağılımı (2015). Figure 5. Distribution of vc types of Cryphonectria parasitica in Izmir Regional Directorate of Forestry (2015). 


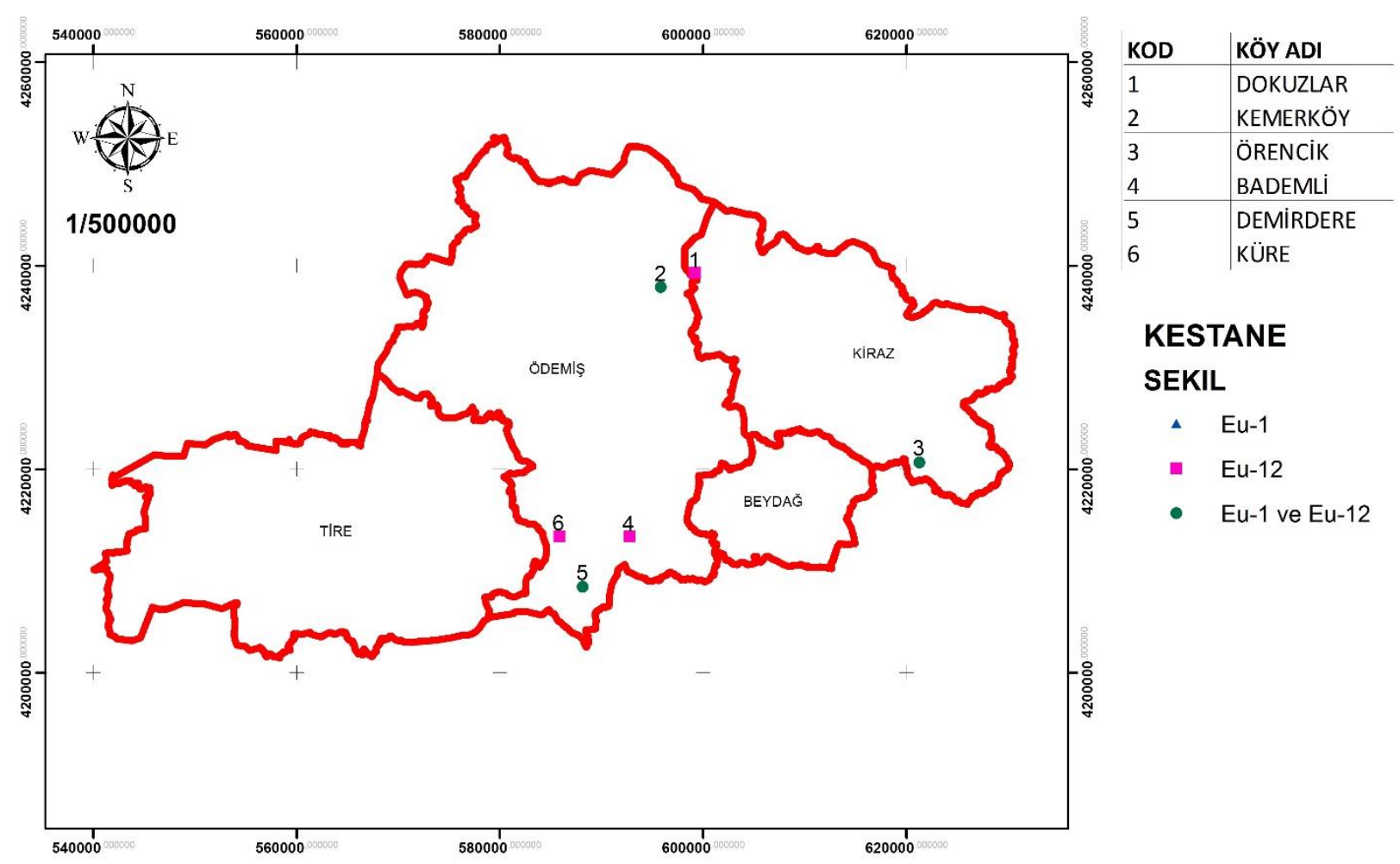

Şekil 6. İzmir yöresinde kestane kanseri etmeni Cryphonectria parasitica'nın uyum tiplerinin dağılımı (2016).

Figure 6. Distribution of Cryphonectria parasitica vc types in Izmir (2016).

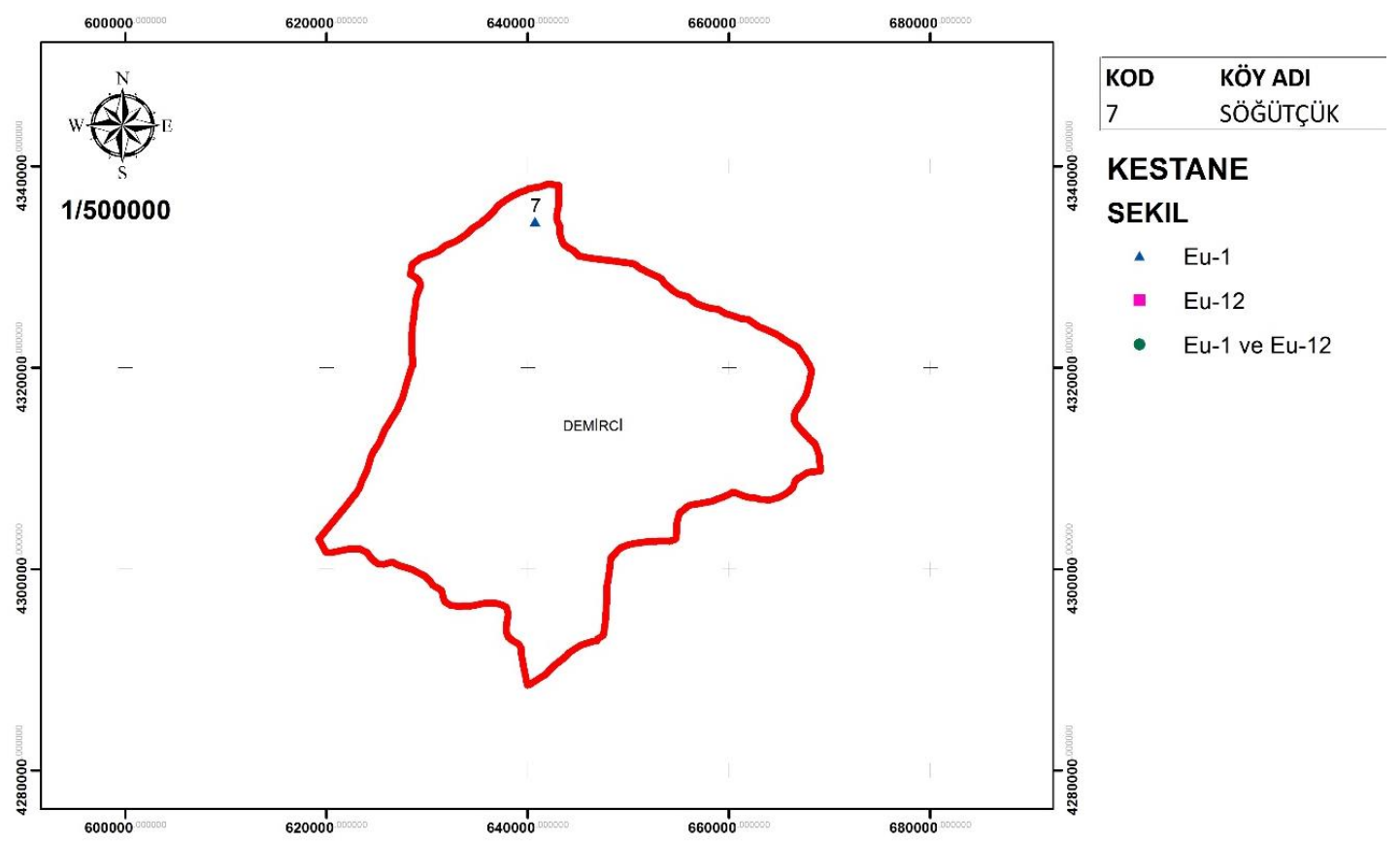

Şekil 7. Manisa yöresinde kestane kanseri etmeni Cryphonectria parasitica'nın uyum tiplerinin dağılımı (2016).

Figure 7. Distribution of Cryphonectria parasitica vc types in Manisa (2016).

\section{Bolu Orman Bölge Müdürlüğü Sınırlarında Yapılan Hipovirülenslik Değerlendirmesi}

Bolu Orman Bölge Müdürlüğü'ne bağlı 4 işletme müdürlüğü (Akçakoca, Düzce, Yığılca ve Gölyaka)'nden 107 kabuk örneği alınmıştır. Bu bölgede doğal hipovirülenslik yaygın bulunmuş ve arazideki kanserlerin iyileşme durumu ile laboratuvar sonuçları birbirini desteklemiştir (Şekil 8, Çizelge 2, Çizelge 3, Çizelge 4, Çizelge 5). Hipovirülenslik yaygın olduğu halde sahalarda bazı bölmelerde tamamen kurumuş kestane ağaçları görülmüştür. Bu ağaçların üzerinde iyileşmiş bir ya da daha fazla kanserli doku olduğu tespit edilmiştir. 
Çakar ve ark., Bolu ve İzmir Orman Bölge Müdürlüğü Kestane Ormanlarında Kestane Kanseri Etmeni Cryphonectria parasitica'nın Uyum Tiplerinin Tespiti ve Hipovirülenslik Değerlendirilmesi

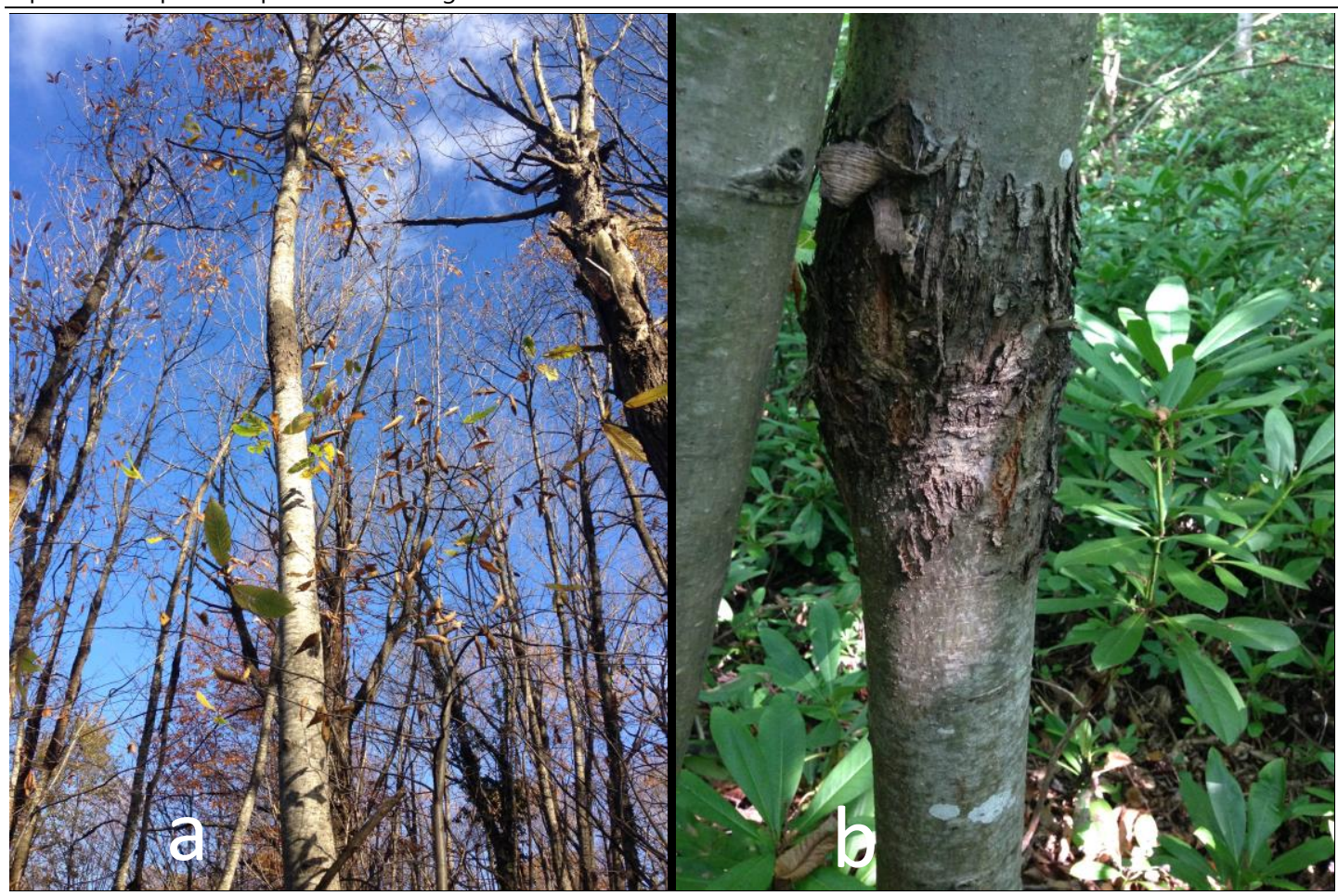

Şekil 8. Akçakoca (a) ve Yığılca (b) Orman İşletme Müdürlüğü sınırlarından doğal hipovirülensliğin görünümü. Figure 8. View of naturel hyphovirulent canker in Akçakoca (a) and Yığılca (b) in Bolu Regional Directorate of forestry.

Çizelge 2. Bolu Orman Bölge Müdürlüğü sınırlarında kestane kanseri açısından değerlendirilen Akçakoca Orman İşletme Müdürlüğü'ne bağlı bölmeler.

Table 2. The stands evaluated for chestnut canker belonging to Akçakoca Regional Directorate of Forestry in terms of in Bolu Regional Directorate of forestry.

\begin{tabular}{|c|c|c|c|c|}
\hline Şeflik Adı & $\begin{array}{c}\text { Bölme } \\
\text { No }\end{array}$ & $\begin{array}{l}\text { Meşcere } \\
\text { Tipi* }^{*}\end{array}$ & $\begin{array}{l}\text { Alanı } \\
\text { (ha) }\end{array}$ & $\begin{array}{c}\text { Hipovirülenslik Varlığı } \\
\text { (Yüzde)** }\end{array}$ \\
\hline \multirow{19}{*}{ 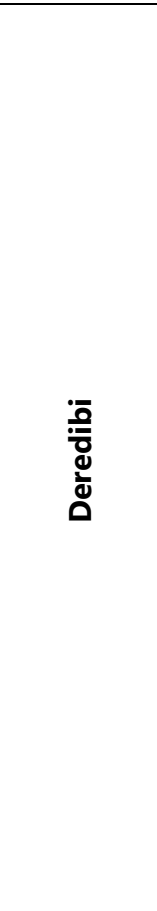 } & 65 & KnKsB & 47.8 & 96 \\
\hline & 41 & KsKnbc2 & 52.6 & + \\
\hline & 39 & KsKnbc2 & 29.5 & + \\
\hline & 38 & KnKsB & 21.4 & 74 \\
\hline & 40 & KnKscd3 & 51.9 & 96 \\
\hline & 43 & KnKsÇmbc3 & 62.7 & + \\
\hline & 42 & KnKsB & 49.7 & + \\
\hline & 64 & KnKscd3 & 20.5 & 79 \\
\hline & 79 & KnKsbc3 & 5.4 & 80 \\
\hline & 58 & KsKnbc3 & 26.2 & 86 \\
\hline & 57 & KnKscd3 & 11.2 & 80 \\
\hline & 36 & KnKscd3 & 4.1 & 86 \\
\hline & 34 & KsKnbc3 & 18.5 & + \\
\hline & 35 & KnKsbc3 & 19.7 & + \\
\hline & 44 & KnKsGnbc3 & 18.7 & + \\
\hline & 67 & KnKsGnbc3 & 58.3 & + \\
\hline & 66 & KnKsD & 26.4 & + \\
\hline & 54 & KnKsÇmbc3 & 6.41 & + \\
\hline & 11 & Kscd3 & 3.7 & + \\
\hline \multirow{7}{*}{ 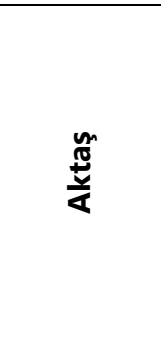 } & 16 & KnKsB & 20.3 & 68 \\
\hline & 14 & Knd3 & 34.6 & 60 \\
\hline & 26 & KnD3 & 19.7 & 72 \\
\hline & 27 & Kncd3 & 29.8 & + \\
\hline & 44 & Kncd3 & 24.0 & 51 \\
\hline & 45 & Knd3 & 6.5 & 51 \\
\hline & 46 & KnKsbc3 & 17.6 & 74 \\
\hline
\end{tabular}




\begin{tabular}{|c|c|c|c|c|}
\hline Şeflik Adı & $\begin{array}{c}\text { Bölme } \\
\text { No }\end{array}$ & $\begin{array}{l}\text { Meşcere } \\
\text { Tipi* }^{*}\end{array}$ & $\begin{array}{l}\text { Alanı } \\
\text { (ha) }\end{array}$ & $\begin{array}{c}\text { Hipovirülenslik Varlığı } \\
\text { (Yüzde)** }\end{array}$ \\
\hline \multirow{8}{*}{$\frac{\text { ț }}{\frac{\pi}{\alpha}}$} & 48 & KnKsB & 47.3 & 84 \\
\hline & 16 & KnKsB & 20.3 & + \\
\hline & 40 & KnKscd3 & 8.1 & + \\
\hline & 56 & KnKscd3 & 10.4 & 86 \\
\hline & 57 & KsKnbc3 & 13.5 & 62 \\
\hline & 60 & KsKnbc3 & 2.2 & 80 \\
\hline & 61 & KsKncd3 & 22.0 & + \\
\hline & 13 & KnKscd3 & 10.0 & + \\
\hline \multirow{8}{*}{ 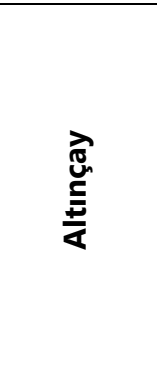 } & 16 & KsGnbc3 & 3.8 & 58 \\
\hline & 5 & KsKncd2 & 12.6 & + \\
\hline & 19 & KsKncd2 & 9.3 & 56 \\
\hline & 31 & KnKsGnb3 & 20.9 & 73 \\
\hline & 32 & KnKsbc3 & 3.3 & 73 \\
\hline & 34 & KnKsGnb3 & 9.2 & + \\
\hline & 46 & KsGnbc3 & 1.2 & 72 \\
\hline & 48 & KsGnbc3 & 15.2 & + \\
\hline \multirow{4}{*}{ 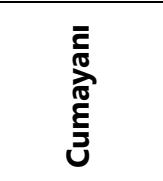 } & 94 & KnKscd3 & 8,5 & 82 \\
\hline & 79 & KnKscd2 & 28 & 87 \\
\hline & 88 & KsKncd2 & 3.2 & 96 \\
\hline & 83 & KnKsD & 29.9 & + \\
\hline
\end{tabular}

*Ks: Kestane; Kn: Kayın; Gn: Gürgen; Çm: Sahil çamı; a,b,c,d: ağacın gelişim çağları; 2,3: Meşcerenin kapalılık oranları, B: genç çap genç yaşta bireylerin yoğun olduğu seçme ormanı D: Değişik yaşlı ve çaplı seçme ormanı.

** +; Sahada gözlemsel olarak hipovirülenslik \%50 olarak değerlendirildi ve bu sahalarda dal kurumaları mevcut.

Çizelge 3. Bolu Orman Bölge Müdürlüğü sınırlarında kestane kanseri açısından değerlendirilen Düzce Orman İşletme Müdürlüğü'ne bağlı bölmeler.

Table 3. The stands belonging to Düzce Regional Directorate of Forestry evaluated in terms of chestnut canker in Bolu Regional Directorate of forestry.

\begin{tabular}{|c|c|c|c|c|}
\hline Şeflik Adı & $\begin{array}{l}\text { Bölme } \\
\text { No }\end{array}$ & $\begin{array}{l}\text { Meşcere } \\
\text { Tipi }\end{array}$ & $\begin{array}{l}\text { Alanı } \\
\text { (ha) }\end{array}$ & $\begin{array}{c}\text { Hipovirülenslik Varlığı } \\
\text { (Yüzde) }\end{array}$ \\
\hline \multirow{12}{*}{ 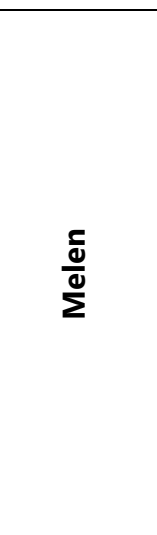 } & 16 & KsihKncd3* & 1.9 & + \\
\hline & 17 & KslhKncd3* & 3.9 & 64 \\
\hline & 18 & KslhKncd3* & 1.6 & + \\
\hline & 19 & KslhKncd3* & 26.2 & + \\
\hline & 21 & KnKsbc3 & 4.6 & 92 \\
\hline & 26 & KslhKncd3 & 13.1 & 96 \\
\hline & 27 & KslhKncd3 & 2.0 & + \\
\hline & 29 & KnKscd3 & 7.9 & + \\
\hline & 30 & KnKsbc3 & 13.4 & + \\
\hline & 187 & KnKscd3 & 10.2 & + \\
\hline & 160 & KslhKncd3* & 11.0 & + \\
\hline & 191 & KnKsGnc3 & 21.5 & 54 \\
\hline \multirow{9}{*}{$\begin{array}{l}\frac{}{\overline{0}} \\
\frac{2}{3} \\
\underline{0} \\
\underline{0}\end{array}$} & 52 & KsKnbc3 & 2.1 & + \\
\hline & 25 & KnKsbc3 & 40.3 & + \\
\hline & 28 & KnKsbc3 & 20.5 & + \\
\hline & 27 & KnKsbc3 & 9.7 & + \\
\hline & 27 & KsKnbc3 & 21.9 & + \\
\hline & 47 & KsKnbc3 & 29.6 & + \\
\hline & 60 & KsKnbc3 & 32.4 & + \\
\hline & 60 & KsKnbc3 & 5.1 & + \\
\hline & 58 & KsGnlhbc3* & 15.6 & + \\
\hline
\end{tabular}

*lh: Ihlamur. 
Çakar ve ark., Bolu ve İzmir Orman Bölge Müdürlüğü Kestane Ormanlarında Kestane Kanseri Etmeni Cryphonectria parasitica'nın Uyum Tiplerinin Tespiti ve Hipovirülenslik Değerlendirilmesi

Çizelge 4. Bolu Orman Bölge Müdürlüğü sınırlarında kestane kanseri açısından değerlendirilen Yığılca Orman İşletme Müdürlüğü'ne bağlı bölmeler.

Table 4. The stands belonging to Yığılca Regional Directorate of Forestry evaluated in terms of chestnut canker in Bolu Regional Directorate of forestry.

\begin{tabular}{|c|c|c|c|c|}
\hline Şeflik Adı & Bölme No & Meşcere Tipi & Alanı (ha) & $\begin{array}{c}\text { Hipovirülenslik } \\
\text { Varlığı } \\
\text { (Yüzde) }\end{array}$ \\
\hline \multirow{4}{*}{$\begin{array}{l}\frac{0}{0} \\
\frac{0}{0} \\
\frac{\pi}{\pi} \\
\underline{\frac{\pi}{0}}\end{array}$} & 27 & Ksd1 & 5.1 & 80 \\
\hline & 28 & KnKsDycd2* & 4.3 & 72 \\
\hline & 25 & KnKscd2 & 13.7 & + \\
\hline & 25 & KnKsbc3 & 14.4 & + \\
\hline \multirow{2}{*}{$\frac{5}{\frac{0}{0}} \frac{0}{0}$} & 19 & KnKsbc1 & 2.5 & 80 \\
\hline & 20 & KnKscd3 & 8 & 64 \\
\hline
\end{tabular}

*Dy: Diğer yapraklılar

Çizelge 5. Bolu Orman Bölge Müdürlüğü sınırlarında kestane kanseri açısından değerlendirilen Gölyaka Orman Iş̧letme Müdürlüğü'ne bağlı bölmeler.

Table 5. The stands belonging to Gölyaka Regional Directorate of Forestry evaluated in terms of chestnut canker in Bolu Regional Directorate of forestry.

\begin{tabular}{|c|c|c|c|c|}
\hline Şeflik Adı & $\begin{array}{c}\text { Bölme } \\
\text { No }\end{array}$ & $\begin{array}{l}\text { Meşcere } \\
\text { Tipi }\end{array}$ & Alanı (ha) & $\begin{array}{c}\text { Hipovirülenslik Varlığı } \\
\text { (Yüzde) }\end{array}$ \\
\hline \multirow{3}{*}{ 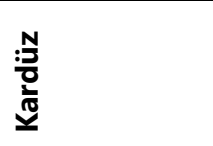 } & 28 & KnKsGncd2 & 13.8 & + \\
\hline & 11 & KnKsGncd2 & 11.9 & + \\
\hline & 12 & KnKscd2 & 10.7 & + \\
\hline
\end{tabular}

\section{Izmir Yöresinde Hipovirülenslik Değerlendirmesi}

İzmir yöresinde 2015 yılı Mart ayı itibariyle 4 ilçeye bağlı 34 köyden toplanan 409 kabuk örneğinden 359 C. parasitica izolatı elde edilmiştir. 2016 yılında ise İzmir ilinde 2 ilçeye bağlı 6 köy ve Manisa ilinde 1 ilçeye bağlı 1 köyden toplanan 52 kabuk örneğinden 50 C. parasitica izolatı elde edilmiştir. Yapılan çalışmada İzmir yöresinden toplanan 409 izolatın hepsi virülent olarak bulunmuştur. Bu bölgede doğal olarak hipovirülensliğe rastlanmamıştır.

\section{TARTIŞMA}

Kestane'nin dünyada en yaygın görülen iki önemli hastalığı vardır. Bunlar kestane kanseri ve Phytophthora kök çürüklüğüdür. Bu hastalıklardan kestane kanseri, kestane ağacının yetiştiği hemen her yerde görülmektedir. Kestane ağaçlarında kurumalara ve verim düşüklüğüne neden olan bu hastalık ülkemiz kestane sahalarında da görülmekte ve ciddi kayıplara yol açmaktadır. Bu çalışma sonuçları önceki çalışmalarda (Çeliker ve Onoğur,1998, 2009; Erincik ve ark., 2011; FAO, 2014; Daldal, 2015) vurgulanan hastalığın Ege Bölgesinde yaygın ve zararlı olduğunu doğrulamıştır. Ayrıca kestane kanserinin Bolu bölgesinde de yaygın olduğu, ancak bu bölgede hipovirülensliğin de yoğun olarak bulunduğu belirlenmiştir.

Kestane kanseri ile mücadelede dünyada kullanılan en etkin ve başarılı yöntem biyolojik savaştır. Biyolojik savaşın temelinde kanserlerin vejetatif uyum tipine uygun hipovirülent izolatların uygulanması yatmaktadır. Bu çalışmayla Bolu ve İzmir bölgelerinde kestane kanserinin uyum tipleri tespit edilmiştir.

Çalışma kapsamında öncelikle Bolu Orman Bölge Müdürlüğü kestane sahalarında hastalık değerlendirilmesi ve uyum tipi tespiti çalışmaları yapılmıştır. Bu bölgeden iyileşmiş kanserlerden örnekler alınmıştır. Hipovirülent kanserlerden alınan örneklerin bazıları morfolojik olarak virülent izolat görünümünde gelişim göstermiş olduğundan Bavendamm testine tabi tutulmuştur. Bu testin sonuçlarına göre 13 örnekten 10 tanesi hipovirülent olarak bulunmuştur. Sonuç olarak iyileşen yani hipovirülent kanserlerde de bazı kısımlarda virülent kanser etmeni bulunabilir ve bu nedenle bu tip kanserlerden her zaman hipovirülent kanser elde edilmesi beklenilmemelidir (Akıllı, 2008; Bryner ve ark.,2013). Bu sonuçlar da bu bakımdan olağandır. Bu yörede hipovirülenslik yaygın olduğu için gelecekte yapılacak çalışmalarda kullanılabilecek yeni hipovirülent izolatlar elde edilmiştir. Bu bölgede hakim olan uyum tiplerinin önceki çalışmalarda (Akıllı ve ark., 2009) elde edilen sonuçlarla uyumlu olduğu bulunmuş, bölgede EU-1 uyum tipinin yaygın olduğu saptanmıştır. Bolu bölgesinde Avrupa uyum tiplerinde dağılım \%97.2 EU-1, \%2.8 EU-12 olarak tespit edilmiştir. Sahalarda yaygın bir şekilde hipovirülenslik tespit edilmiştir. Bazı sahalarda aşırı olarak tam kurumuş ağaçlar görülmüştür. Bu sahalar için silvikültürel ve sanitasyon önlemleriyle 
Çakar ve ark., Bolu ve İzmir Orman Bölge Müdürlüğü Kestane Ormanlarında Kestane Kanseri Etmeni Cryphonectria parasitica'nın Uyum Tiplerinin Tespiti ve Hipovirülenslik Değerlendirilmesi

mekanik mücadele yapılmalıdır. Tam kurumuş ağaçların çok olduğu alanlarda Phytophthora kök çürüklügünün olabileceği düşünülmektedir. Bu sahaların başka bir araştırma kapsamında detaylı olarak ele alınmasına gerek vardır. Bolu yöresinde kestane ormanlarında genel olarak meyve verimi hastalıklardan dolayı az olup, özellikle Yığılca Orman İşletme Müdürlüğü'nde sahiplenilmiş ve bahçe olarak kullanıldığı görülen kestaneliklerin veriminin daha iyi olduğu gözlenmiştir. Bolu yöresinde gezilen karışık meşcerelerde kestane ağaçlarının daha sağlıklı olduğu gözlemlenmiştir. Sahalarda hipovirülenslik yaygın bulunmuş olup, iyileşmiş alanlarda çok fazla dal kurumları da gözlenmiştir. İyileşmiş ağaçların üzerine bulunan tam kurumuş dalların bulunması, bu sahada daha önceden aktifliğin var olduğunu ve zaman içinde hipovirülensliğin yaygınlaşmasıyla iyileşmelerin başladığını ve ince dallarda kanserin dalı tam olarak kuşatmasından dolayı dal ölümlerinin gerçekleştiği düşünülmektedir.

Çalışmanın Ege Bölgesinde yürütülen kısmında hiç iyileşme gösteren kansere rastlanmamıştır. Elde edilen tüm izolatlar virülent özellikte gelişme göstermiştir. Bu bölgede \%37.6 EU-1, \%62.4 EU-12 uyum tipi dağılımı tespit edilmiştir. Bu da elde edilen verilerin daha önceki bulgularla uyumlu olduğunu göstermektedir (Erincik ve ark., 2011; FAO, 2014).

\section{SONUÇ}

Araştırma sonucuna göre, İzmir ve Bolu yöresinde kestane kanseri etmeninin uyum tipleri açığa kavuşturulmuş ve bu bölgede en yaygın uyum tiplerinin EU-1 ve EU-12 olduğu belirlenmiştir. Uyum tipi çeşitliliğiniz az olması özellikle doğal hipovirülensliğin olmadığı İzmir gibi bölgelerde biyolojik mücadelenin başarısını artıracaktır. Uyum çeşitliliği az olan bu bölgelerde biyolojik mücadele çalışmaları devam ettirilmelidir. Bu yörede hemen hemen tamamen aşılı kestane yetiştiriciliği yapıldığı için, dışardan aşı kalemi getirme olasılığı vardır ve ilerde değişik uyum tiplerinin bölgeye sokulması mümkündür. Ayrıca doğal mutasyonlarla da genetiği yakın uyum tipleri oluşabilir. Bu nedenle bölgede biyolojik savaşın sürekliliği için uzun süreli çalışmalara gerek vardır. İzmir Orman Bölge Müdürlüğü sınırlarında kestane kanseri dışında başka hastalıklar da gözlenmiştir. Tamamen kurumuş çok sayıda kestane ağacına rastlanmıştır. Bu kurumaların birçoğunun yürütülen bir çalışmada (Ankara Üniversitesi BAP 15B0447002 No'lu proje) Phytophthora kök çürüklüğünden kaynaklandığı bulunmuştur. Bolu yöresinde hipovirülenslik yaygın bulunmuş olup, bu çalışmalara devam edilmeli ve hipovirülensliğin \%50'den az olduğu bölgelerde biyolojik mücadele çalışmaları başlatılmalıdır. Yine bu bölge de uyum tipi çeşitliliğinin az olması biyolojik mücadele çalışmalarının başarısını arttıracaktır. Bölgelerde aşı çalışması yapılacak ise yöre dışından aşı kalemleri getirilmemelidir.

\section{ÇIKAR ÇATIŞMASI}

Yazarlar olarak bu makalenin planlanması, yürütülmesi ve yazılması konusunda bir çıkar çatışması olmadığını beyan ederiz.

\section{YAZAR KATKISI}

Deniz ÇAKAR, Seçil AKILLI ŞiMŞEK, Salih MADEN ve Y. Zekai KATIRCIOĞLU çalışmanın planlanması, yürütülmesi ve laboratuvar çalışmalarını yürütmüştür. Deniz ÇAKAR ve Tuncay CAN arazi çalışmalarının planlanması ve örneklerin toplanması işlemlerini yürütmüştür.

\section{TEŞEKKÜR}

Bu çalışma; Orman Genel Müdürlüğü / Batı Karadeniz Ormancılık Araştırma Enstitüsü Müdürlüğü'nün yürütücülüğünü yaptığı "Bolu ve İzmir Ormanlarında Kestane Kanseri Hastalığı (Etmen: Cryphonectria parasitica (Murr.))'nın Hipovirülent İzolatlarla Biyolojik Savaşımı" projesinden derlenmiştir. Orman Genel Müdürlügü̈'ne, Batı Karadeniz Ormancılık Araştırma Enstitüsü Müdürlüğü'ne, İzmir Orman Bölge Müdürlüğü çalışanlarına, Swiss Federal Institute for Forest, Snow and Landscape Research, WSL (Isviçre Federal Orman, Kar ve Peyzaj Araştırmaları Enstitüsü) fitopatoloji takım lideri Dr. Daniel Rigling'e, Bursa Orman Bölge Müdürlüğü'nde görevli Orman Mühendisi Hacer CAN'a, Bolu II Özel İdaresi'nde görevli Orman Yüksek Mühendisi Müjdat ULUDAĞ'a ve orman köylüsüne teşekkür ederiz. 
Çakar ve ark., Bolu ve İzmir Orman Bölge Müdürlüğü Kestane Ormanlarında Kestane Kanseri Etmeni Cryphonectria parasitica'nın Uyum Tiplerinin Tespiti ve Hipovirülenslik Değerlendirilmesi

\section{KAYNAKLAR}

Allemann, C., Hoegger, P., Heiniger, U., \& Rigling, D. (1999). Genetic variation of Cryphonectria hypoviruses (CHV1) in Europe, assessed using restriction fragment length polymorphism (RFLP) markers. Molecular Ecology, 8(5), 843-854

Akıllı, S. (2008). Karadeniz Bölgesinde kestane kanseri (C. parasitica)'nin biyolojik mücadelesi üzerine araştırmalar. Doktora Tezi, Ankara Üniversitesi Fen Bilimleri Enstitüsü, Bitki Koruma Bölümü, Ankara.

Akıllı, S., Katırcıoğlu Y. Z., \& Maden S. (2009). Vegetative Compatibility Types of Cryphonectria parasitica, Chestnut Blight Agent, in Black Sea Region. Forest Pathology, 39(6), 390-396.

Akıllı, S., Ulubaş-Serçe Ç., Katırcıoğlu Y. Z., Maden S., \& Rigling D. (2013). Characterization of hypovirulent isolates of the chestnut blight fungus, Cryphonectria parasitica from the Marmara and Black Sea regions of Turkey. European Journal of Plant Pathology, 135, 323-334.

Anagnostakis, S., (1977). Vegetative incompatibility in Endothia parasitica. Experimental Mycology, 1, $306-316$.

Anagnostakis, S. L., Hau, B., \& Kranz, J. (1986). Diversity of vegetative compatibility groups of Cryphonectria parasitica in Connecticut and Europe. Plant Disease, 70, 536-538.

Anagnostakis, S. L. (1987). Chestnut blight- the classical problem of an introduced pathogen. Mycologia, 79, 23-37.

Anagnostakis, S. L. (2001). American chestnut sprout survival with biological control of the chestnut-blight fungus population. Forest Ecology and Management, 152(1-3), 225-233.

Barr, M. E. (1978). The Diaporthales in North America with emphasis on Gnomonia and its sagregates. Mycologia Memoir, 7, 1-232.

Bissegger, M., Rigling, D., \& Heiniger, U. (1997). Population structure and disease development of Cryphonectria parasitica in European Chestnut forest in the presence of natural hypovirülence. Phytopathology, 87, 50-59.

Bryner, S. F., Sotirovski, K., Akıllı, S., Risteski, M., Perlerou, C., \& Rigling, D. (2013). Informative value of canker morphology on the presence or absence of virus infection in chestnut blight cankers. Forest Pathology, 43(6), 496-504.

Coşkun, H., Turchettı, T., Maresi, G., \& Santagada, A. (1999). Preliminary investigations into Cryphonectria parasitica (Murr) Barr isolates from Turkey. Phytopathology Mediterranean, 38, 101-110.

Çeliker, N. M., \& Onoğur, E. (1998). Determining the hypovirulence in the chestnut blight (Cryphonectria parasitica [Murr.] Barr.) in Turkey. The Journal Turkish Phytopathology, 27, 145-146.

Çeliker, N. M., \& Onoğur, E. (2009). Biological control of chestnut blight and prospect for future: Turkey as a case study. Acta Horticulturea, 815, 221-226.

Chung, P., Bedker, P. J., \& Hillman, B. I. (1994). Diversity of Cryphonectria parasitica hypovirulence-associated doublestranded RNAs within a chestnut population in New Jersey. Phytopathology, 84(9), 984-990.

Daldal, M. (2015). İzmir, Manisa, Muğla ve Denizli illerinde Cryphonectria parasitica populasyonlarinin vejetatif uyum grupları ve mating tipler yönünden karakterizasyonu. Yüksek Lisans Tezi, Adnan Menderes Üniversitesi, Fen Bilimleri Enstitüsü, Aydın.

Döken, M. T., Açıkgöz, S., Erincik, Ö., \& Ertan, E. (2004). Studies in the chestnut growing areas of Aydın-Turkey to determine the incidence of Cryphonectria parasitica (Murill) Barr infections (Chestnut Blight) and vegetative compatibility group diversity among the isolates. Türkiye 1. Bitki Koruma Kongresi, Samsun.

Elliott, K. J., \& Swank, W. T. (2008). Long-term changes in forest composition and diversity following early logging (19191923) and the decline of American chestnut (Castanea dentata). Plant Ecology, 197, 155-172.

Enebak, S. A., MacDonald, W. L., \& Hillman, B. I. (1994). Effect of dsRNA associated with isolates of Cryphonectria parasitica from the central Appalachians and their relatedness to other dsRNAs from North America and Europe. Phytopathology $84,528-534$.

Erincik, Ö., Özdemir, Z., Durdu, Ö. F., Döken, M. T., \& Acikgöz, S. (2011). Diversity and spatial distribution of vegetative compatibility types and mating types of Cryphonectria parasitica in the Aydın Mountains, Turkey. European Journal of Plant Pathology, 129, 555-566.

Evans, A. M., \& Finkral, A. J. (2010). A new look at spread rates of exotic diseases in North American forests. Forest Science, $56,453-459$.

EPPO (2005). European and Mediterranean plant protection organization. Cryphonectria parasitica. EPPO Bulletin, 35, 295298.

FAO (2014). Management of chestnut blight and for improving forest health and vitality (2012-2014), Report, TCP/TUR/615676. 
Çakar ve ark., Bolu ve İzmir Orman Bölge Müdürlüğü Kestane Ormanlarında Kestane Kanseri Etmeni Cryphonectria parasitica'nın Uyum Tiplerinin Tespiti ve Hipovirülenslik Değerlendirilmesi

FAOSTAT (2019). FAO (Food and Agricultural Organization of The United Nation). http://www.fao.org/faostat/en/\#data/QC/visualize. Erişim tarihi: 29 Aralık 2020

Fulbright, D. W., Weidlich, W. H., Haufler, K. Z., Thomas, C. S., \& Paul, C. P. (1983). Chestnut blight and recovering American chestnut trees in Michigan. Canadian Journal of Botany, 61(12), 3164-3171.

Griffin, G. J. (1986). Chestnut blight and its control. Horticultural Reviews, 8, 291-336.

Griffin, G. J. (1999). Frequencies and spatial patterns of white hypovirulent and pigmented strains of Cryphonectria parasitica within blight-controlled cankers on grafted American chestnut trees 15-16 years after inoculation. European Journal of Forest Pathology, 29(6), 377-390.

Griffin, G. J., Robbins N., Hogan, E. P., \& Farıas-Santopıetro, G. (2004). Nucleotide sequence identification of Cryphonectria hypovirus infecting Cryphonectria parasitica on grafted American chestnut trees 12-18 years after inoculation with hypovirulent strain mixture. Forest Pathology, 34, 33-46.

Gürer, M., Turchetti, T., Biagioni, P., \& Maresi, G. (2001). Assessment and characterisation of Turkish hypovirulent isolates of Cryphonectria parasitica (Murr) Barr. Phytopathologia Mediterranea, 40, 265-275.

Heiniger, U., \& Rigling, D. (1994). Biological control of chestnut blight in Europe. Annual Review Phytopathology, 32, 581599.

Hillman, B. I., Tian, Y., Bedker, P. J., \& Brown, M. P. (1992). A North American hypovirulent isolate of the chestnut blight fungus with European isolate-related dsRNA. Journal of General Virology, 73(3), 681-686.

Hillman, B. I., Halpern, B. T., \& Brown, M. P. (1994). A viral dsRNA element of the chestnut blight fungus with a distinct genetic organization. Virology, 201(2), 241-250.

Jaynes, R. A., \& Elliston, J. E. (1980). Pathogenicity and canker control by mixtures of hypovirülent strains of Endothia parasitica in American chestnut. Phytopathology, 70, 453-456.

Katırcıoğlu, Y. Z., Akıllı Şimşek, S., \& Maden, S. (2017). Ege bölgesi kestane (Castanea sativa) alanlarında kurumalara neden olan Phytophthora türleri ve yaygınlıklarının belirlenmesi (2015-2017). Ankara Üniversitesi, Bilimsel Araştırma Projesi Final Raporu. 15B0447002, Ankara.

Lee, S. H., Park, J. Y., Kim, K. H., \& Lee, J. K. (2005). Characteristics of hyovirulent strains of chestnut blight fungus, Cryphonectria parasitica isolated in Korea. Proceedings of Third International Chestnut Congress. Acta Horticulture, 693, 611-616.

Liu, Y. C., Double, M. L., MacDonald, W. L., \& Milgroom, M. G. (2002). Persistence of Cryphonectria hypoviruses after their release for biological control of chestnut blight in West Virginia forests. Forest Pathology, 32(6), 345-356.

Liu Y-C, Hillman BI, Linder-Basso D, Kaneko S, Milgroom MG. 2003. Evidence for interspecies transmission of viruses in natural populations of filamentous fungi in the genus Cryphonectria. Molecular Ecology, 12, 1619-1628.

Mangıl, E. (2017). Doğu Karadeniz Bölgesinde kestane kanseri etmeni Cryphonectria parasitica'nın vejetatif uyum tipi çeşitliliğinde eşeyli üremenin rolü. Yüksek Lisans Tezi, Adnan Menderes Üniversitesi, Aydın.

Marra, R. E., \& Milgroom, M. G. (1999). PCR amplification of the mating-type idiomorphs in Cryphonectria parasitica. Molecular Ecology, 8, 1947-1950.

Melzer, M. S., \& Boland, G. J. (1999). CHV3-type dsRNAs and the GH2 genotype in a population of Cryphonectria parasitica in Ontario. Canadian Journal of Plant Pathology, 21(3), 248-255.

Milgroom, G. M., \& Cortesi, P. (2004). Biological control of chestnut blight with hypovirulence; a critical analysis. Annual Review Phytopathology, 42, 311-338.

Myburg, H., Gryzenhout, M., Wingfield, B. D., Milgroom, M. G., Kaneko, S., \& Wingfield, M. J. (2004). DNA sequence data and morphology define Cryphonectria species in Europe, China and Japan. Canadian Journal of Botany, 82, 89-98.

OGM (2014a). Orman ve Su İşleri Bakanlığı, Orman Genel Müdürlüğü, Kestane Eylem Planı 2013-2017.

OGM (2014b). FAO ve Orman Genel Müdürlüğü, Kestane Hastalıklarına Karşı Standart Çalışma Yöntemleri 2014

Peever, T. L., Liu Y., Cortesi, P., \& Milgroom, M. G. (2000). Variation in tolerance and virulence in the chestnut blight fungushypovirus interaction. Applied and Environmental Microbiology, 66(11), 4863-4869.

Peever, T. L., Liu, Y. C., \& Milgroom, M. G. (1997). Diversity of hypoviruses and other double-stranded RNAs in Cryphonectria parasitica in North America. Phytopathology, 87(10), 1026-1033.

Peever, T. L., Liu, Y. C., Wang, K., Hillman, B. I., Foglia, R., \& Milgroom, M. G. (1998). Incidence and diversity of doublestranded RNAs occurring in the chestnut blight fungus, Cryphonectria parasitica, in China and Japan. Phytopathology, 88(8), 811-817. 
Çakar ve ark., Bolu ve İzmir Orman Bölge Müdürlüğü Kestane Ormanlarında Kestane Kanseri Etmeni Cryphonectria parasitica'nın Uyum Tiplerinin Tespiti ve Hipovirülenslik Değerlendirilmesi

Perlerou, C., \& Diamandis, S. (2006). Identification and geographic distribution of vegetative compatibility types of Cryphonectria parasitica and occurrence of hypovirulence in Greece. Forest Pathology, 36, 413-421.

Rigling, D., Heiniger, U., \& Hohl, H. R. (1989). Reduction of laccase activity in ds-RNAcontaining hypovirulent strains of Cryphonectria (Endothia) parasitica. Phytopathology, 79, 219-223.

Rigling, D., \& Prospero, S. (2018). Cryphonectria parasitica, the causal agent of chestnut blight: invasion history, population biology and disease control. Molecular Plant Pathology, 19(1), 7-20.

Roane, M. K., Griffin, G. J., \& Elkins, J. R. (1986). Chestnut blight, other Endothia diseases, and the genus Endothia. The American Phytopathological Society, St. Paul, Minnesota, USA. 